NBER WORKING PAPER SERIES

ECONOMIC BACKWARDNESS AND CATCHING UP:

BRAZILIAN AGRICULTURE, 1964-2014

\author{
Lee Alston \\ Bernardo Mueller \\ Working Paper 21988 \\ http://www.nber.org/papers/w21988
NATIONAL BUREAU OF ECONOMIC RESEARCH
1050 Massachusetts Avenue
Cambridge, MA 02138
February 2016

The views expressed herein are those of the authors and do not necessarily reflect the views of the National Bureau of Economic Research.

NBER working papers are circulated for discussion and comment purposes. They have not been peerreviewed or been subject to the review by the NBER Board of Directors that accompanies official NBER publications.

(C) 2016 by Lee Alston and Bernardo Mueller. All rights reserved. Short sections of text, not to exceed two paragraphs, may be quoted without explicit permission provided that full credit, including $\odot$ notice, is given to the source. 
Economic Backwardness and Catching Up: Brazilian Agriculture, 1964-2014

Lee Alston and Bernardo Mueller

NBER Working Paper No. 21988

February 2016

JEL No. N56,Q15

\begin{abstract}
Alexander Gerschenkron understood the development of backward countries as a contextual process that varied from country to country depending on which perquisites were present or absent. In the past twenty years, Brazilian agriculture evolved from "backward" to an agricultural powerhouse. Its production and total factor productivity more than doubled. Brazil is in the worlds' top five producers of coffee, soybeans, oranges, beef and corn. Yet, some segments of agriculture lag far behind. We draw on the insights of Gerschenkron and Albert Hirschman, inter alia to conceptualize the development process. As an illustrative aid we apply fitness landscapes to the process of development. Fitness landscapes are good representations of a contextual view of development. We portray the process as an evolutionary search for good designs across a large, uncertain and not pre-statable set of possibilities. In such circumstances a controlled strategy of following predetermined stages is not effective. Rather we need an approach relying on creativity and imagination to find solutions to specific problems faced by each country.
\end{abstract}

\author{
Lee Alston \\ Ostrom Workshop and Department of Economics \\ Indiana University \\ 513 N. Park Avenue \\ Bloomington, IN 47408-3895 \\ and NBER \\ ljalston@indiana.edu \\ Bernardo Mueller \\ Department of Economics \\ University of Brasilia \\ bmueller@unb.br
}




\title{
Economic Backwardness and Catching Up: Brazilian Agriculture, 1964-2014
}

\author{
Lee Alston and Bernardo Mueller
}

What can be derived from a historical review is a strong sense for the significance of the native elements in the industrialization of backward countries.

—Alexander Gerschenkron ([1962] 1965: 26; emphasis added)

\begin{abstract}
Alexander Gerschenkron understood the development of backward countries as a contextual process that varied from country to country depending on which perquisites were present or absent. In the past twenty years, Brazilian agriculture evolved from "backward" to an agricultural powerhouse. Its production and total factor productivity more than doubled. Brazil is in the worlds' top five producers of coffee, soybeans, oranges, beef and corn. Yet, some segments of agriculture lag far behind. We draw on the insights of Gerschenkron and Albert Hirschman, inter alia to conceptualize the development process. As an illustrative aid we apply fitness landscapes to the process of development. Fitness landscapes are good representations of a contextual view of development. We portray the process as an evolutionary search for good designs across a large, uncertain and not pre-statable set of possibilities. In such circumstances a controlled strategy of following predetermined stages is not effective. Rather we need an approach relying on creativity and imagination to find solutions to specific problems faced by each country.
\end{abstract}

\section{Introduction}

In the nineteenth century and through much of the twentieth, modernization or economic development was equated with industrialization. Gerschenkron, one of the titans of economic history, assessed the industrialization of France, Germany, and Russia in a comparative fashion. He does not dispute the role of industrialization in catching up with economies that had already industrialized, but he was ahead of his time by noting the contextual nature of development. France, Germany, and Russia all industrialized in different ways. It seems almost part of human nature to presume that there is a template for economic development. The notions of 'leading sectors', 'Import Substitution', and the 'Washington Consensus' have all had their day in the sun.

Industrialization seemed a likely candidate for imitation because it was technology that could be reverse engineered and backward countries could borrow from the already 
industrialized world and leap forward. ${ }^{1}$ Gerschenkron notes that countries that industrialized did so rapidly, but they needed certain prerequisites. First, industrialization needs to be financed. In France and Germany, banks played a role, though in Germany banks were more directly involved with the industries that they financed rather than simply lending. In contrast, in Russia, banking in the late nineteenth century was primitive, so the state played a big role by directly or indirectly taxing its citizens to finance rapid industrialization. All three countries industrialized, though only France and Germany fully developed. ${ }^{2}$ Gerschenkron was ahead of his time in recognizing that to industrialize (or modernize), countries had to have the right ideology of entrepreneurship, whether state or privately led:

To break through the barriers of stagnation in a backward country, to ignite the imaginations of men to place their energies in the service of economic development a stronger medicine is needed than the promise of a better allocation of resources.... Or the prospect of profits. What is needed to remove the mountains of routine and prejudice is faith—faith, ... that the golden age lies not behind but ahead of mankind. (Gerschenkron [1962] 1965: 24)

Gerschenkron's argument presages the pathbreaking work of Joel Mokyr (2009), who argued that it was the internalization in Britain of the enlightenment ideals that man could change nature that led to Britain being the first to industrialize. Similarly, Deirdre McCloskey $(2006,2010)$ maintains that the ideas are paramount to institutions for development. For McCloskey, the idea that work had dignity allowed Britain to be the first to industrialize. Beliefs form an umbrella over the dominant network in society when they choose which institutions to put in place to achieve desired economic or political outcomes. This is the underlying premise of Alston et al. (forthcoming). Of course, desired outcomes do not always mean economic or political development. Many in the dominant network of power prefer the status quo because of the rents that they derive.

The notion that industrialization is still a sufficient condition has been abandoned for a more nuanced view that institutions matter. ${ }^{3}$ Some still come close to presuming that there is an

\footnotetext{
${ }^{1}$ We hear the same argument invoked about China today.

${ }^{2}$ At the time of Gerschenkron's writing, the West vastly overestimated the GDP of the Soviet Union and its satellites.

${ }^{3}$ If industrialization was sufficient, Brazil would have begun its developmental trajectory in the 1930s when the state supported industry and unions.
} 
institutional template. ${ }^{4}$ To say that institutions matter does not give much insight into just which institutions mattered, where, and how. In addition, institutions cannot be transplanted, as Gerschenkron well understood.

\section{Fitness Landscapes as a Heuristic to Understand Economic Development}

In this section, we explore fitness landscapes as a different way of looking at Gerschenkron's approach to economic backwardness. Fitness landscapes are a useful heuristic for understanding development as a search process. A backward country that seeks to develop must choose a set of institutions that it believes will provide the rules and constraints on economic, political, and social life that will, in turn, induce the desired outcomes. ${ }^{5}$ But there is an extremely large variety of institutions that can be put in place, and considerable uncertainty as to the effect that each specific set will yield. That is, the country knows what results it wants to achieve and knows the set of possible institutions, but it does not have full information on the mapping from one to the other. The country can look at the example of other countries, but that will only partially help, as each country’s experience is, to a large extent, idiosyncratic. So inevitably, each nation has to induce the relationship it expects to exist between institutions and outcomes, that is, it forms and relies on beliefs of how the world works. Fitness landscapes provide a useful way to portray and analyze the process of forming beliefs and searching through a large design space of institutions for appropriate development strategies for backward countries. ${ }^{6}$

Assume that a set of institutions can be described as a series of $N$ dimensions, each related to a specific characteristic of the institutions. These dimensions could be things like economic inclusion, political inclusion, role of state vs. market, rate of time preference, role of religion, the individual vs. the collective, social capital and trust, globalization vs. inwardness, racial discrimination, attitude toward the environment, and so on. In order to simplify, consider that each dimension can be either present or absent (e.g., the institutions are either inclusive or

\footnotetext{
${ }^{4}$ See, for example, Acemoglu and Robinson (2012), who come close with the notion that societies cannot be extractive to develop, but rather need to be inclusive. We agree, but there are many shades of inclusiveness and hence not a recipe.

${ }^{5}$ We use institutions rather than proximate conditions of development familiar at Gerschenkron's time of writing (e.g., industrialization or financial intermediation).

${ }^{6}$ Fitness landscapes (or adaptive landscapes) were originally devised by Sewall Wright (1932) in order to provide a visual method to understand how evolution searches for fit genotype design. Kauffman $(1993,1995)$ extended and gave more rigor to the treatment of fitness landscapes.
} 
extractive) so that a specific set of institutions can be described as a string of $N$ zeros or ones. There are thus $2^{\mathrm{N}}$ different combinations of possible institutions from which a country can choose. As $N$ becomes larger, the number of possibilities grows very fast; with $N=10$ there are 1,024 combinations. If the dimensions were more finely gradated instead of being binary, the number of combinations would equal $A^{N}$ (where $A$ is the number of values the dimension can take), which could easily reach an astronomical number of possible institutions. The process of searching for combinations that promote good results, that is, the search for a development strategy, is therefore not a trivial task. A country cannot simply try every combination and choose that which works best. On the other hand, it is not totally blind, as there are the examples of other countries as well as theory and logic, which can serve as guides. The process of development can therefore be conceptualized as a search strategy that can be analyzed using the heuristic of fitness landscapes.

In order to construct a fitness landscape, it is first necessary to create the design space of all possible institutions, which arrays along a plane the possible combinations of institutions. To do this, start out with a given configuration of institutions, that is, a $N$-dimensional bit-string of zeros and ones, and place surrounding it each one-bit mutation that flips a single 1 to a 0 (or vice versa). The resulting plane (the design space) contains every possible combination of institutions. ${ }^{7}$ For each element in the plane, we can then plot the fitness of those institutions on the third (vertical) axis. In the case of biology, the fitness of a genotype is clear. It represents the ability of that design to replicate in the given environment. ${ }^{8}$ Designs with higher fitness will thus tend to dominate over time in the population. For institutions and other social substrates, the notion of fitness is not as direct. Fitness still involves the notion that the specific design is able to perpetuate itself in the future, but it is easier to think of this as being the case because that design is achieving the desired and expected outcomes and so is not being radically changed by that society. In this perspective, the height of the landscape represents the success of that specific development strategy. Because the bit-strings are arrayed alongside other very similar bit-strings,

\footnotetext{
${ }^{7}$ There are some mathematical limitations of this approach as it seeks to plot multiple dimensions into a low dimension space, but it is useful because it facilitates visualization. A more rigorous approach uses Boolean hypercubes (see Kauffman 1993). For more discussion on this point and a different approach, see McCandlish (2011).

${ }^{8}$ Note that it is the phenotype- the actual rendered design-that reproduces or fails to do so. Nevertheless, it is ultimately the genotype, that is, the set of instructions on how to design the phenotype, that is being evolved.
} 
they will not usually have very different levels of fitness, so the resulting landscapes will tend to be relatively smooth, though, as we shall see, this may not always be the case.

Figure 1 shows three different classes of fitness landscapes. Panel A shows a smooth (Mount Fuji) landscape where there is a single superior development strategy. In these circumstances, it is relatively easy to find the best solution as simple search strategies, such as a hill-climbing algorithm, will easily reach the best design. The rugged landscape in panel B presents a more difficult challenge, as there are many local optima where a hill-climbing strategy might get stuck. Furthermore, if the landscape is large, it is difficult to even know which is the best design, as there are too many peaks to compare. In panel C, there is no relation between the fitness of neighboring designs, so the landscape is essentially random and even more difficult to search.

(Figure 1 about here)

What determines the shape of a given landscape is the degree to which there are interrelationships among the different dimensions, that is, complementarities and substitutability among, say, the economic and political inclusion. ${ }^{9}$ If the dimensions are all independent, then the search process can tune each dimension without setting back optimal designs already found for other dimensions, and the result is a smooth landscape. Furthermore, the single peak will exhibit high levels of fitness because there are few limiting constraints. But, if every single dimension is connected to every other dimension, then every minute change in design has repercussions on every other dimension leading to a random landscape. Because there are so many internal constraints, there is not only an unwieldy number of peaks but they reach only relatively low levels of fitness. If, on the other hand, there are only a moderate number of interconnected dimensions, the landscape will be rugged, with more than one peak, but not a chaotic configuration. In this scenario, a simple hill-climbing search process risks getting trapped on suboptimal solutions, even when there are better designs nearby. A search process based on variation, selection, and replication — that is, Darwinian evolution-turns out to be particularly well-suited for searching rugged landscapes. The variation that takes place due to recombination or mutation allows for experimentation of non-contiguous designs, thus permitting jumps across nearby valleys to other potentially higher peaks.

\footnotetext{
${ }^{9}$ In genetics, these interrelationships are called epistatic links between the individual genes. They exist when, for example, the fitness contribution of a gene for beak length affects the fitness contribution of the gene for wing shape.
} 


\subsection{Coevolution and Dancing Landscapes}

Besides the internal configuration of each design, its fitness level also depends on the design of other entities that inhabit the same environment, competing or cooperating for resources. Thus, the fitness of a given design of a frog is contingent on the designs of its predators, preys, symbionts, and parasites. When a variation gives a fly better wings, the fitness of that frog's current design goes down. This means the frog's landscape has shifted. Coevolution thus causes linked landscapes to dance over time, which means that the search process is never over, but rather requires constant adaptation. In this sense, the ability to constantly adapt to changing circumstances is more important than the actual current design.

For a country's institutions, the level of fitness is linked to changes in physical and social technologies as well as the institutions adopted by competing and cooperating countries. When a new disruptive technology emerges, or when a competing country becomes fitter, the current institutions of a given country lose fitness, causing the landscape to dance.

When landscapes dance, there is a perpetual need for adaption to new circumstances. In smooth landscapes, this adaptation is difficult because when the single peak recedes and pops up unexpectedly elsewhere, the new optimal design may be far away, and by the time it is reached the landscape will have danced again. Thus, the average level of fitness will be low over time. In random landscapes, the dancing involves the (already low fitness) spikes thrusting up and down chaotically, making it impossible to adapt. Once again, the average level of fitness over time is low, half the time you are on a low peak and the other half in an even lower trough. In rugged landscapes, however, when the peak you are on recedes, a new different peak is bound to pop up relatively nearby, allowing the design to adapt reasonably quickly to the dancing landscape. Even if it does not adapt to the global optimum, the average level of fitness over time will be relatively high, as you spend much time on or near reasonably high peaks. Because rugged landscapes maintain higher levels of fitness than smooth or random landscapes, it is believed that most coevolutionary processes tend to evolve toward this type of configuration, that is, an evolution of evolution (Kauffman 1995). We therefore assume, when applying these concepts to economic development, that in this substrate too, rugged landscapes best represent the problem faced by developmental strategies. 


\subsection{Economic Backwardness and Stages of Growth as Fitness Landscapes}

From the above, a fitness landscape can be viewed as portraying the problem that a country faces in choosing the institutions that will constrain and shape its development. Let us see how these concepts can give us a different way to understand Gerschenkron's approach to economic backwardness. ${ }^{10}$ Although institutions change incrementally all the time, this takes place under a stable set of beliefs of how the world works. While the outcomes match the beliefs, there will not be much pressure for change. But often the beliefs are not good descriptions of how things really work, and outcomes will eventually deviate from what is expected. When this happens, there will be a window of opportunity or a critical juncture where elites, beliefs, and institutions may be replaced (see Alston et al. forthcoming for a detailed description of these relationships). It is at this point, when new beliefs are emerging, that the landscapes are most useful as an analytical device.

The new dominant coalition is faced with the immense plane of possible institutional designs and must choose a single specific set that it deems most conducive to its desired objectives. It does not view the landscape that contains the information on the fitness of each design. The actual landscape is invisible to them. Also, there are too many possibilities to go by trial and error, so they cannot reveal the actual landscape by experimentation. They therefore have to conjure up a notion, an estimate, a guess, of what would be the consequence of each combination they might consider. This is what we are calling a 'belief'. They use their own past experience, that of other countries, theory, instinct, and any other means at their disposal to create a mental map of the fitness of each possible set of institutions. Thus, although they do not see the actual landscape, they see a landscape informed by their beliefs.

An example of the problem of choosing institutions in terms of fitness landscapes is given in Figure 2. The actual relationship between institutions and outcomes is the lower landscape with two humps. This tells us that the best course of action would be to choose institutions

\footnotetext{
${ }^{10}$ Fitness landscapes have had a deep impact in the study of evolutionary biology. Nevertheless, there is wide disagreement on how useful they actually are. It is very common to see fitness landscapes referred to as a 'metaphor' and the debate then centres on how useful or misleading is the metaphor (see, e.g., Pigliucci 2012 and Skipper and Dietrich 2012 for different sides in the debate). McCloskey (1991) argues at length that the strength of Gerschenkron's approach was the recognition that social theories are metaphors, that is, 'tales constrained by facts'. So even if one chooses to see fitness landscapes as metaphors, they can nevertheless provide a different way to understand Gerschenkron’s approach.
} 
represented by point $B$, which would yield the highest level of fitness possible in this environment, that is, $A B$. But the actual relationship is not observed, and the country has to rely on its beliefs, which are represented by the higher plane. As drawn, these beliefs are quite far from the actual, they are not really a good guide for a development strategy. Based on these beliefs, institutions at point $D$ will be chosen, with an expectation of outcomes corresponding to $C D$. But the actual fitness will be much lower than expected. This distance between the expected and the actual will eventually emerge in the form of poor outcomes along several measures, bringing with it disappointment and frustration, inducing a new window of opportunity for change, though it might take some time for the society to admit its beliefs are mistaken.

(Figure 2 about here)

Let us now use these concepts to characterize Gerschenkron's theory of economic backwardness. This theory is often contrasted with Rostow's The Stages of Economic Growth (1960), which postulates that economic modernization follows a series of universal predefined stages. As noted by McCloskey (1991), Gerschenkron was going against a much more unified and prevalent view:

Gerschenkron's chief scientific accomplishment was to undermine the metaphor of social stages which had dominated nineteenth-century and much twentiethcentury thought. Henry Maine, Auguste Comte, Friedrich List, Karl Marx, Werner Sombart, Bruno Hildebrand, and lately Walt Rostow, thought of a nation as a person, with predictable stages of development from birth to maturity. If the stage theorists viewed the child as the father of the man, Gerschenkron was a new Freud, noting the pathologies arising from retarded growth. (McCloskey 1991: 95)

Similarly, Fenoaltea (2014) stresses the contraposition between views of development that expect a single universal path versus another where development can take many different and unexpected paths:

The analysis developed by Alexander Gerschenkron is less widely known, but far richer than Rostow's one-dimensional scheme. To Gerschenkron’s mind the most interesting aspect of the industrialization of backward countries is that it does not await the fullness of time: the take-off (or "great spurt" as he prefers to call it) begins even before all the canonical prerequisites are in place, thanks to innovative solutions that create substitutes for the missing prerequisites. (Fenoaltea 2014: 9) 
This contrast is illustrated in Figure 3. The top panel portrays a world where there is a clear single set of institutions that best induces development. ${ }^{11}$ It is a view of the world beset by universal propositions. This was a powerful view in the mid-twentieth century because most developed countries at that time could, at least weakly, have their development trajectories portrayed as having followed a similar path. But Gerschenkron, looking at the problem faced by backward countries in a world where the pioneers had already developed, realized that there were actually several different contextual paths with different consequences depending on which prerequisites were present or absent. That is:

In this area the first conclusion that Gerschenkron arrived at was that Marx's generalization - that "the industrially more developed country presents to the less developed country a picture of the latter's future" — was only partially true, and possibly trivially so. What was more relevant for him was that most often, the industrialization process in a backward country was substantially different-not just in terms of speed, but also in nature-from that in an advanced country. This obviously meant that countries that were different-in terms of the degree of their backwardness - would also be characterized by different processes of industrialization. (Chandrasekhar 2005: 182)

(Figure 3 about here)

Such a world is portrayed in terms of fitness landscapes in the middle panel of Figure 3 . It is important to bear in mind that each country faces its own individual landscape that depends on its own specific circumstance, that is, there are few, if any, universal propositions. At the very least, the fact that backward countries have templates to learn from (or to be misled by) already assures that their context is different from that of the pioneer countries that had no such guides. But also, there are many different development strategies that yield relatively high fitness. Because of the rugged nature of the landscape, there is a risk of being trapped in relatively low local peaks. Furthermore, the actual landscape is not observed, so it is not the case of simply tweaking the institutions until you reach the highest peak. Instead, a country will often be faced with disappointing and unexpected results, and it may not be obvious how to set things right.

One way or another, the country will have to form beliefs of what the landscape looks like and use those as a guide to pursue better outcomes. A natural strategy is to follow Rostow's

${ }^{11}$ Both the Stages of Economic Growth and the Economic Backwardness theories overwhelmingly discuss development as being affected by policies and not in terms of institutions. We adapt the discussion to fit the current consensus that institutions are the fundamental determinants of the policies, which have a more proximate effect. 
notion of universal stages and presume that the development problem that is being faced is similar to that faced by the countries that have already successfully developed. In the lower panel in Figure 3, the backward country is facing the unobserved rugged landscape from the middle panel and has formed beliefs based on the perceived experience of the developed countries in the upper panel. These beliefs induce the choice of institutions at point $B$ and create an expectation of fitness commensurate with $A B$, which will not be realized. The best development strategy would have been institutions at point $D$, which would induce a fitness level of $C D$. Thus, a country can go through an endless series of development strategies never reaching the desired outcomes, which seems to be a good description of the trajectory of a large number of countries in the past centuries.

Besides the empirical evidence of multiple paths to development that the world has witnessed since the time of Gerschenkron and Rostow, the mathematical structure of landscapes also indicates that development is best portrayed as a hard problem with many competing solutions, rather than one with a clear winning path. Any reasonable definition of the dimensions that make up a country's institutions is bound to have many interrelationships among those dimensions. Institutions composed of perfectly orthogonal dimensions would not be very realistic. Since the number of interrelationships mathematically determines the ruggedness of the fitness surface, this implies that development is probably best characterized as a search along a rugged landscape, as in the middle panel of Figure 3, instead of the single-peaked landscape of the upper figure.

Development is an even harder problem than this. As noted earlier, due to coevolution with technologies and other countries, the landscape actually changes over time, with tectonic shifts making what were good solutions in the past no longer fit for the backward countries of the present. Although we do not explore this issue here, this propensity for shifting landscapes probably means that more so than specific development strategies, what is most important is the capability to adapt to the ever-changing problems that are thrown in a country's way. For example, the lack of authoritarian governments among currently developed countries may be an indication that the higher ability of democracies to adapt is a crucial characteristic of a successful development strategy. 


\subsection{The Hiding Hand Principle-That which does not destroy me, makes me stronger}

A related use of fitness landscapes is to illustrate the Hiding Hand Principle. Although this was put forward by Albert Hirschman and not by Alexander Gerschenkron, the idea is highly compatible with the theory of economic backwardness. Gerschenkron and Hirschman had a long and intertwined relationship. ${ }^{12}$ Malcolm Gladwell recently described Hirschman's Hiding Hand Principle as follows:

People don't seek out challenges. They are "apt to take on and plunge into new tasks because of the erroneously presumed absence of a challenge-because the task looks easier and more manageable than it will turn out to be.” This was the Hiding Hand principle—a play on Adam Smith's Invisible Hand. The entrepreneur takes risks but does not see himself as a risk-taker, because he operates under the useful delusion that what he's attempting is not risky. Then, trapped in mid-mountain, people discover the truth—and, because it is too late to turn back, they're forced to finish the job. (Gladwell 2013; original emphasis)

Note that when Gladwell uses the term 'trapped mid-mountain,' it conjures up the image of fitness landscapes, which we will use below to illustrate Hirschman's idea.

Cass Sunstein (2014), in a preface to a new edition of Hirschman's 1967 Development Projects Observed, discusses the two reasons that Hirschman offers to explain why planners are so prone to underestimating obstacles and challenges. Both of these explanations are directly relevant to the discussion above about Gerschenkron's approach of economic backwardness.

He calls the first the "pseudo-imitation" technique, which means that planners pretend, or think, "that a project is nothing but a straightforward application of a well-known technique that has been successfully used elsewhere." The devastating problem, of course, is that situations and circumstances are different,

\footnotetext{
${ }^{12}$ For an outstanding biography of Hirschman, see Adelman (2013), upon whom I draw. Hirschman's first position in the United States in 1941 was under a Rockefeller Fellowship working on a project on trade regulation headed by Professors Condriffe and Ellis at the University of California, Berkeley. Gerschenkron was also hired to work on the project, and he and Hirschman shared an office. After Pearl Harbor, the fellowships ran out. A hiatus between the two followed, but coincidentally, Professor Ellis (who was now at the Federal Reserve Board) hired Gerschenkron, who quickly rose up the ranks to become head of the international section. Following Hirschman's return from the war in Europe, Gerschenkron hired Hirschman and they became colleagues again. They parted ways in 1948, when Harvard hired Gerschenkron. Over the next decade and a half, they corresponded on their overlapping work. In 1964, Gerschenkron was the force behind Harvard hiring Hirschman. Ten years later, Gerschenkron was instrumental once again by championing Hirschman for a position at the Institute for Advanced Studies at Princeton.
} 
so a project that is sold as if it were pure imitation usually has a large component of "indigenous initiative and execution". (Sunstein 2014)

This is a near-perfect restatement of Gerschenkron's critique of viewing development as composed of universal propositions.

The second explanation given by Sunstein for why planners are so often deluded is that:

planners dismiss previous efforts as piecemeal, and portray their own effort as a comprehensive program. With this technique, policymakers give, and are given, the illusion "that the 'experts' have already found all the answers", and all that is needed is faithful implementation. Those who enlist the pseudo-comprehensiveprogram technique end up underplaying the need for "imagination, insight, and the application of creative energies", thus covering up "the ignorance of the experts about the real cure of the malady they have been summoned to examine”. (Sunstein 2014)

Here again, the notion of development strategies requiring only 'faithful implementation', rather than creativity and imagination to make the most of unexpected opportunities to deal with unexpected problems, is reminiscent of Gerschenkron’s critique.

Figure 4 illustrates how Hirschman’s Hiding Hand Principle can be conceptualized through fitness landscapes. The upper panel shows a country’s belief regarding the fitness of different institutions as a developmental strategy. Possibly the country is following the example of other countries that have already been successful with the strategy indicated by point $A$, and, as drawn, it believes that is basically the only way forward. The expectation is that this will induce outcomes with a high fitness level equal to $A B$. But things do not really turn out as expected by those beliefs, and the actual outcome is a fitness of only AC. This is an inferior outcome that undermines the previously held beliefs; things turn out not to work as the overly optimistic planners expected. But now that the country is already at point $A$ and with the information gleaned from failure, the country may sometimes find itself in an unexpected vantage point to adopt a different developmental strategy that it had not perceived before. Being at $A$ has revealed the true landscape (or new beliefs closer to the true landscape), as portrayed in the lower panel of Figure 4. The old mistaken belief is superimposed on the new, more accurate belief. From its failure the country can, with newfound creativity and imagination, find the ridge that allows a transition from its low-level current peak to a new development strategy at $E$, that might be even 
better than what they had initially expected at $A$, that is, it may be that $D E>A B .{ }^{13}$ Hirschman suggests that in many cases, had the country not made the mistake, it would not have achieved those good outcomes.

(Figure 4 about here)

\section{From the Abstract to the Concrete: Brazilian Agriculture; Backward to Cutting Edge}

The fitness landscapes illustrated the difficulty with development strategies. But we can learn a great deal from case studies chronicling success cases. Over time, we may be able to develop some generalizations. In this section, we analyze the remarkable transformation of agriculture in Brazil, which could be characterized as backward in the 1960s to today's characterization of a world agricultural powerhouse.

By any standards, Brazil in 2014 was a global agricultural powerhouse, both in terms of absolute production as well as recent changes in productivity. Figure 5 shows the evolution of production, input use, and total factor productivity (TFP) for Brazilian agriculture since 1975. In three and a half decades, production increased fourfold using the same amount of land and slightly less labor. This impressive result was achieved by the growth of total factor productivity spurred mostly by agricultural research. Figure 6 compares the change in agricultural productivity in Brazil with the United States and with the average value for Europe, Asia, Africa, and Latin America. The comparison shows that the improvements in Brazil were in fact quite exceptional (although it must be taken into account that some countries, such as the United States, already had higher levels at the start of the series and thus would naturally find it harder to achieve additional improvements). In the past decades only China has achieved levels of TFP growth on a par with Brazil. But importantly, Brazil still has, more than any other country, significant areas of unused or degraded land in which to expand production (without counting the Amazon), as well as a favorable endowment of water. Finally, Figure 7 shows how Brazil’s rank in production of the ten most important crops and livestock has changed from 1970 to $2012{ }^{14}$ The first thing to note is that Brazil was already a major producer of most of the major products.

\footnotetext{
13 These ridges are common in biological examples of evolution. They allow an evolution of the genotype from one peak to a more distant peak without going into the perilous regions of low fitness, which might lead to extinction before reaching the second peak.

${ }^{14}$ The list of the world's ten highest value products in 2012 was taken from <http://en.wikipedia.org/wiki/List_of_most_valuable_crops_and_livestock_products>.
} 
Still, over four decades, it increased its rank in all but two (coffee remained first and rice fell one notch). Because all other countries were also simultaneously striving to increase their production, improving the rankings is not a trivial accomplishment.

(Figures 5, 6, and 7 about here)

How did they achieve this? It was certainly not preordained or planned. We assess Brazil's rise in agricultural development using Gerschenkron's criteria of the necessary supporting conditions for industrialization: financial intermediation, the role of the state, and ideology (beliefs). Gerschenkron suggested that if backward countries have these supporting conditions, industrialization would be rapid. We agree that for rapid growth in agriculture you need these conditions, but they are not sufficient. In addition to entrepreneurship at the farm level, you also need the right set of beliefs in the government to establish institutions that will generate modernization in agriculture. Furthermore, agricultural techniques cannot be reversed, engineered, or transplanted from other advanced agricultural areas (e.g., the United States or Europe). Productivity for agriculture is location specific. Soils, climate, precipitation, topography, and temperature, inter alia, matter. We will come back to this point under the role of the state.

\subsection{The Military Years: $1964-1984$}

We treat the twenty years of military rule as one period because throughout this time, the military could rule by decree. A belief in 'developmentalism' shaped the policies of the military government throughout their reign. By developmentalism, we mean state-led growth driven by technocratic planning. The military also held to the strategy in the preceding period of Import Substitution Industrialization (ISI). As a result, the industrialists supported the military regime as long as it produced growth. What did this mean for agriculture? Overall, the belief system had a negative impact at the farm level for promoting entrepreneurship. The government relied on agriculture to generate foreign exchange, especially from coffee and sugar. An overvalued currency was part of the strategy, which was a tax on agriculture. The government provided sufficient subsidized credit in the 1970s to ensure that Brazil was self-sufficient in foodstuff while also earning dear foreign exchange. Over time, it did establish a set of minimum prices to ensure continued expansion in production on the extensive margin, which were the savannahs in the middle of the country. This also served as a safety valve for an ever-expanding population. 
Within the set of developmentalist beliefs, the government had a conflicting set of beliefs that overall negatively affected agriculture. The dominant network in the technocratic military regime believed that rural elites were an obstacle to progress because land brought status and the elite was impervious to technological change in agriculture but instead wished to be viewed as Coronels. ${ }^{15}$ The belief that farmers were immune to economics was part of the reasoning behind the military land reform based on forceful expropriations. Land reform per se was at odds with the developmentalist belief, but the military believed it was necessary because this was the only way to modernize agriculture. Also at odds with the military mentality was its support of rural unions, but only those that supported the military regime.

The dominant network in the military regime also believed that the United States and the rest of the world wanted to take away the Amazon. This belief prompted much of the disastrous colonization and subsidies to promote occupation of the Amazon. Though the Amazon was far away from the rest of settled Brazil, the military falsely thought that they could control the process, but it turned out incredibly harder and more complex than expected. They started colonization of small farmers, mostly from the southeast of Brazil. Most of the projects turned out to be non-profitable in the short run because of the lack of infrastructure and distance from markets. When the colonization strategy failed, Brazil turned to subsidies to large firms. In the 1970s, the military turned to subsidizing large-scale cattle ranching in the Amazon with tax credits. The result was a mixture of some settlement, along with 'phantom' ranches just to receive the tax credits. Landless peasants subsequently initiated land invasions and land conflict, which would dampen the motivation to invest in modernizing agriculture. As such, productivity in agriculture remained flat, and expansion was only on the extensive margin.

On the plus side, the military regime supplied abundant credit at subsidized rates to the rural sector through the National System of Rural Credit. It aimed at promoting modern inputs (e.g., fertilizers, pesticides, and insecticides). Credit supply soared from US\$6.2 billion in 1970 to US\$12.8 billion in 1973 to a maximum of US\$26.8 billion in 1979. Throughout the 1970 s, credit came at negative rates of interest from a low of -1.4 percent (1973) to a high of -37.7 percent

\footnotetext{
${ }^{15}$ The belief was sufficiently strong, even among academics, that it led to a debate as to whether farmers responded to prices or were motivated by power in semi-feudal fashion. A classic paper in the 1960s (Pastore 1968) showed that farmers do respond to prices so that taxes and incentives could be used in agricultural policy.
} 
(1980). The credit boom expanded output and hectares cultivated considerably, but overall productivity remained flat.

Throughout the military regime, they relied on minimum prices, but in a haphazard fashion. The goal of minimum prices was twofold: promote production and promote settlement, especially of the Cerrado, the semi-tropical savannahs. Minimum prices achieved their goals, but they did not promote productivity. Much of the output ended up in government inventories, especially the output in frontier areas that were too far from markets.

Overall, because everyone knew that the military's priority was industrialization, it did not release entrepreneurial zeal among the potential agribusiness community. In terms of Gerschenkron's three conditions—-financial intermediation, state support, and ideology — the military provided enough finance, but agribusiness felt constrained because of the limited opportunities under the umbrella of ISI. Agribusiness also felt threatened by rural unions and the uptick in land conflict and expropriations. On the plus side, the military laid the groundwork for future productivity increases through the initiation of EMBRAPA, a decentralized research organization. In its early years, EMBRAPA appeared more a political boondoggle than a coordinated research strategy. But later, it developed collaborations with universities, much like the USDA. But, it would take years before EMBRAPA paid technological dividends.

Overall, the twenty years of the military regime sent an erratic set of signals to the farmers. Despite the mixed set of signals, the supply of credit and the establishment of minimum prices persuaded a small but increasingly important agribusiness sector that money could be made in agriculture. Significant non-subsidized investment by agribusiness awaited a more consistent set of policies along with a stable macroeconomic environment.

\subsection{Reopening to Democracy and Social Inclusion: 1985-1994}

Unlike most military regimes, Brazil's planned its exit from governing society. Opening up proceeded in stages, with first elections at the state and local level followed by an indirect election for president in 1984. Tancredo Neves won the election amid incredible popular support. Tragically, Tancredo died before assuming office. His death shocked society, and brought uncertainty to the future of Brazil in part because the vice president, Jose Sarney, had been allied with the former military regime. 
After the repressive years of military government, society yearned for and demanded inclusion. Sarney had no choice but to become more inclusive. As an early signal of inclusion, illiterates were given the right to vote simply because the dominant network felt that it was the right thing to do. During the first ten years of redemocratization, the dominant network was large-every interest group had a seat at the table. Rather than forming a coherent economic plan, including agricultural policy, the first order of business was a new constitution formed in 1988. The process was long and protracted, but importantly codified the belief in social inclusion. The constitution was highly aspirational in that it sought reform and redistribution as part and parcel of its raison d'être.

As a result of: the dominant network being large; no leadership among the dominant leaders; and an overarching societal desire for inclusion, every interest group received something. Businesses initially retained high tariff barriers. Rural workers would receive the same benefits as urban workers. Unions gained increasing recognition and labor law favored labor over business. The nascent rising agribusiness sector retained minimum prices and credit, though this was relatively short-lived and as in the military years, policies were erratic. On the downside for agriculture was a new emphasis on land reform. The constitution stated that land should be put into beneficial use, and, if not, the government could expropriate it. This led to an increased incentive for land invasions, which forced the government to act and expropriate in order to limit violence. ${ }^{16}$ The overall impact of social inclusion without a budget constraint was mounting inflation. By the late 1980s until 1993, inflation roared ahead at more than 1,000 percent per annum.

What was the impact on agricultural entrepreneurs and agribusiness? Not as bad as one might have expected. This suggests that agriculture had begun to modernize, though the percentage of farms in the modern sector was small. As is generally the case, there is a large stasis in most government policies because interest groups lobby to retain benefits. For agriculture, this meant that credit continued to be available, though now through different channels, and minimum prices were retained for part of the period. With hyperinflation roaring, the government attempted several plans to quell inflation, but each plan failed because of a lack

\footnotetext{
${ }^{16}$ See Alston, Libecap, and Mueller (2013) for a discussion of land conflict generated by misguided federal policies. See Alston and Mueller (2013) for a discussion of the negative impact of land reform on tenancy and crop choices.
} 
of commitment and leadership to weather the storm. The main obstacle inhibiting the modernization of agriculture in the late 1980s and early 1990s was uncertainty over prices and policies. Uncertainty over policies, particularly inflation, causes investments to fall. Political scandal added to uncertainty. In 1990 and 1991, markets reacted favorably to the election of Fernando Collor, the first directly-elected president since redemocratization. Collor embarked on a series of liberal policies that favored markets that would favor agriculture. But, Collor resigned in 1992 rather than be impeached. Itamar Franco, as vice president, took over, but uncertainty remained. Throughout the first ten years of democracy, the agricultural sector was poised to expand because market forces increasingly mattered, but the macroeconomic and political instability caused would-be investors to wait out the storm.

\subsection{Fiscally Sustainable Social Inclusion: 1994-2014}

Brazil finally tamed hyperinflation with the Plano Real in 1993. Given the numerous plans to stop inflation, the expectations were low for the success of the Plano Real. It was largely the brainchild of a group of US-trained economists brought into policy by the Finance Minister Fernando Henrique Cardoso. The beauty of the plan was twofold: the nuts and bolts; and the messenger. The economists understood technically how to reduce inflation, and Cardoso understood the importance of transparency. In the Plano Real, there were no surprises and it succeeded faster than anticipated. From the success of the Plano Real, Cardoso ran for president and succeeded. He brought two of the architects of the Plano Real on board: Pedro Malan as finance minister, and Gustavo Franco as head of the Central Bank.

The taming of inflation was a punctuated change for Brazil, but it alone would not have been sufficient to modernize Brazilian agriculture or Brazil at large. Under the leadership of Cardoso, Brazil adopted a new belief in the importance of fiscal and monetary orthodoxy wedded to social inclusion-together fiscally sound social inclusion. It took time for Cardoso to convince the dominant network of the importance of sustaining macroeconomic stability, but it took hold with his reelection and was cemented with the election of Lula, who continued to maintain the same beliefs system. After her recent close contest to gain reelection, Dilma has also reaffirmed the belief in fiscally sound social inclusion.

Why is the new belief important for the modernization of agriculture? A stable macroeconomic climate is a necessary condition to prompt long-term investments. Agriculture is 
no exception. Though land can and was used as a hedge against inflation, entrepreneurs prefer clear and stable policies to better assess investment prospects. Government subsidies for agriculture declined, but the government policies toward exports became more favorable and Brazil became a more open economy.

Two other factors importantly aided the modernization of Brazilian agriculture: research and high commodity prices. Agricultural productivity is site-specific, and EMBRAPA transformed itself from a sleepy bureaucracy under the military government and early years of the opening-up into a dynamic collaborative research institute. EMBRAPA can best be thought of as a focal node of a research network tying together research at universities and other research entities tied to farming on the ground. The dividends in research productivity really paid off around 2000. Sustained high commodity prices over the first decade of the twenty-first century further fueled modernization. Both domestic and foreign direct investment flooded into agriculture. Though commodity prices have fallen, Brazil is now an inframarginal producer so that while profits may be lower, they are sufficient to reward the modern sector of Brazilian agriculture.

Modernization has started, but it has a long way to go. More than 50 percent of Brazilian agriculture comes from less than 1 percent of the farms. What is holding back the sector? Agricultural land reform still hampers investment. With the credible threat of an expropriation, frequently the result of a violent land conflict, many farmers do not rent to would-be productive tenants but instead turn land into a less productive use (e.g., pasture). Not only do deaths result but many would-be tenants remain landless. This is particularly harmful to career advancement because agricultural tenancy has been shown to be a step on the way to ownership (Alston and Ferrie 2005). The increase in the landless also leads some would-be tenants to migrate to the Amazon, turning to subsistence agriculture (an extremely low-valued use of land). Migration and subsistence farming also lead to increased deforestation—not an intended outcome of land reform.

Alston and Mueller (2013) show that not only is tenancy too low but land reform policies alter crop mix. The aggregate effects on the amount of hectares in non-optimal use are very large, the size of small countries (e.g., Greece or Portugal). Given that both landowners and the majority of landless peasants would win from a more sensible land reform (e.g., subsidized mortgages), what are the impediments to change? We conjecture that the urban electorate, who favors redistribution of agricultural land and increased ownership by peasants, is unaware of the 
link between land reform and the unintended consequences of land conflicts, reduced tenancy, inefficient farm sizes, and inefficient crop mixes. Politicians respond to votes. Moreover, many politicians too are likely unaware of the consequences of extant land reform policies.

\section{Back to Gerschenkron}

Did being backward enable Brazilian agriculture to modernize faster? Of course, if you are backward, the only way is up. Also, what does faster mean? Mueller and Mueller (2014) date early modernization with the military regime. In this case, it took 36 years for modernization to begin. If we date it from Cardoso, the speed was quite rapid — six years. The slowness can be attributed to the wrong set of beliefs (ideology) held by the dominant network for many years of the impact of institutions on outcomes.

The belief during the military regime in developmentalism led to agricultural policies where the role for agriculture was a means to help industrialization and later to fight inflation. From the mid-1980s, under the new belief umbrella of social inclusion, agriculture should be used to achieve social justice. Under both periods, land reform was seen as the key ingredient for agricultural policy but with different rationales. Only with the belief of fiscally sound social inclusion from the mid-1990s onward did policymakers begin to interfere less with agriculture. This was the beginning of the boom. With hyperinflation tamed and policy stability, private investment took off in some regions. Yet, the modernization reached only a very small part of Brazilian agriculture, in terms of hectares or farms. In addition, though the military established EMBRAPA in the early 1970s, it did not function properly until around 2000. High commodity prices also added fuel to the speed of modernization once it had been set in motion.

The important insight to retain from Gerschenkron and Hirschman is the role of beliefs and absence of template for development. In Gerschenkron's mind, it was the belief of the entrepreneurial spirit that drives development. This matters, as shown by the robust agribusiness in Brazil. Gerschenkron neglected to stress the importance of macro policy stability that sets the incentives for the private sector to invest. For Hirschman, the key message for development is adaptability and the readiness to abandon failure. Brazil experimented with agricultural policy and still continues to do so. They appear to have followed the text of Hirschman's message with lags, but it was not experimentation ex ante but rather by default. 


\section{References}

Acemoglu, D. and J. A. Robinson, 2012. Why Nations Fail: The Origins of Power, Prosperity, and Poverty. New York: Random House.

Adelman, J., 2013. Worldly Philosopher. Princeton, NJ: Princeton University Press.

Alston, L. J., and J. Ferrie, 2005. 'Time on the Ladder: Career Mobility in Agriculture, 18901938'. Journal of Economic History vol. 65 number 4:1058-81.

Alston, L. J., G. Libecap, and B. Mueller, 2013. Interest Groups, Information Manipulation in the Media, and Public Policy: The Case of the Landless Peasants Movement in Brazil. NBER Working Paper No. 15865, March.

Alston, L. J., M. Melo, B. Mueller, and C. Pereira, Forthcoming 2016. Brazil in Transition: Beliefs, Leadership, and Institutional Change. Princeton, NJ: Princeton University Press.

Alston, L.J., and B. Mueller, 2013. Tenancy, Conflict and Priests in Brazil. Working Paper, January, University of Colorado. NBER Working Paper No. 15771 (June).

Chandrasekhar, C. P., 2005. 'Alexander Gerschenkron and Late Industrialization'. In The Pioneers of Development Economics: Great Economists on Development, edited by K. S. Jomo. New Delhi: Tulika Books.

Fenoaltea, S., 2014. The Reinterpretation of Italian Economic History. Cambridge, MA: Cambridge University Press.

Gasques, J., E. T. Bastos, C. Valdes, and M. Bacchi, 2012. 'Total Factor Productivity in Brazilian Agriculture'. In Productivity Growth in Agriculture: An International Perspective, edited by O. F. Keith, S. L. Wang, and E. Ball. Oxfordshire, UK: CAB International.

Gerschenkron, A., [1962] 1965. Economic Backwardness in Historical Perspective: A Book of Essays. New York: F. Praeger.

Gladwell, M., 2013. 'The Gift of Doubt: Albert O. Hirschman and the Power of Failure'. The New Yorker, Books, June 24.

Hirschman, Albert O. 1967. Development Projects Observed. Washington, DC: Brookings Institution Press.

Kauffman, S., 1993. The Origins of Order: Self-Organization and Selection in Evolution. New York: Oxford University Press.

Kauffman, S., 1995. At Home in the Universe. New York: Oxford University Press.

McCandlish, D. M., 2011. 'Visualizing Fitness Landscapes'. Evolution vol. 65 number 6:154458.

McCloskey, D., 1991. 'Kinks, Tools, Spurts, and Substitutes: Gerschenkron’s Rhetoric of Relative Backwardness'. In Patterns of European Industrialization: The Nineteenth Century, edited by Richard Sylla and Gianni Toniolo. London: Routledge.

McCloskey, D., 2006. Bourgeois Virtues: Ethics for an Age of Commerce. Vol. 1 of 4 on 'The Bourgeois Era.' Chicago, IL: University of Chicago Press.

McCloskey, D., 2010. Bourgeois Dignity: Why Economics Can't Explain the Modern World. Vol. 2 of 4 on 'The Bourgeois Era.' Chicago, IL: University of Chicago Press.

Mokyr, J., 2009. The Enlightened Economy: An Economic History of Britain, 1700-1850. New Haven, CT: Yale University Press.

Mueller, B., and C. Mueller, 2014.The Economics of the Brazilian Model of Agricultural Development. International Research Initiative on Brazil and Africa (IRIBA). IRIBA Working Paper 01. Manchester, UK: University of Manchester.

Pastore, A. C., 1968. 'A Resposta da Produção aos Preços no Brasil.’ Boletim 55, FCEA-USP. 
Pigliucci, M., 2012. 'Landscapes, Surfaces, and Morphospaces? What are They Good For?' In The Adaptive Landscape in Evolutionary Biology, edited by E. Svensson and R. Calsbeek. New York: Oxford University Press.

Rostow, W., 1960. The Stages of Economic Growth. New York: Cambridge University Press.

Skipper, R. A., and M. R. Dietrich. 2012. 'Sewall Wright's Adaptive Landscape? Philosophical Reflections on Heuristic Value'. In The Adaptive Landscape in Evolutionary Biology, edited by E. Svensson and R. Calsbeek. New York: Oxford University Press.

Sunstein, C., 2014. 'Albert Hirschman's Hiding Hand'. Foreword to a reissued edition of Albert Hirschman’s Development Projects Observed. Washington, DC: Brookings Institution Press.

Wright, S., 1932. 'The Roles of Mutation, Inbreeding, Crossbreeding, and Selection in Evolution.' In Proceedings of the Sixth International Congress of Genetics, vol. I, edited by Donald F. Jones, 356-66. Menasha, WI: George Banta Publishing. 


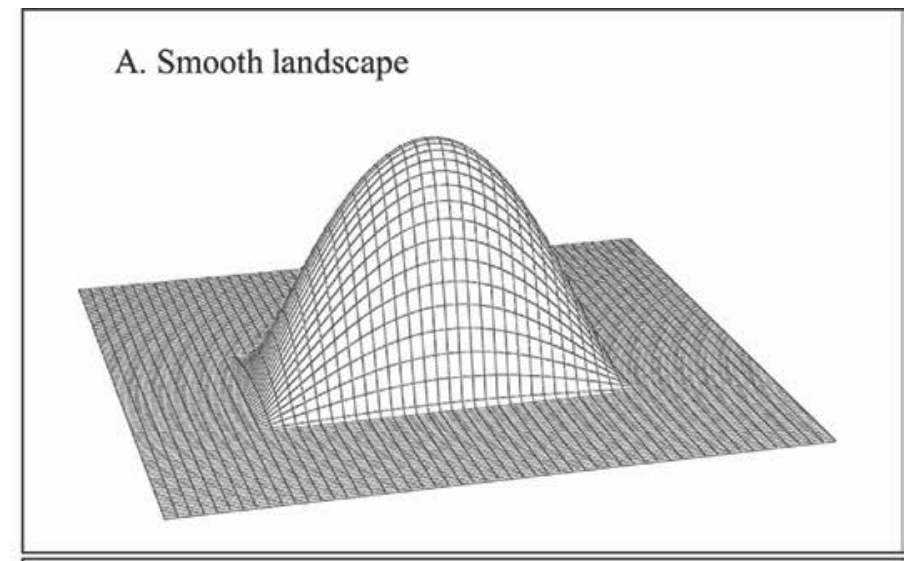

B. Rugged landscape

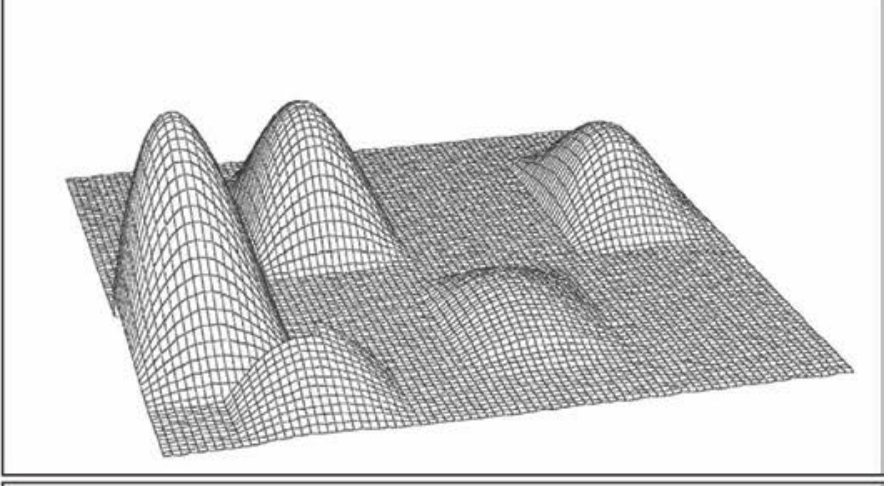

C. Random landscape

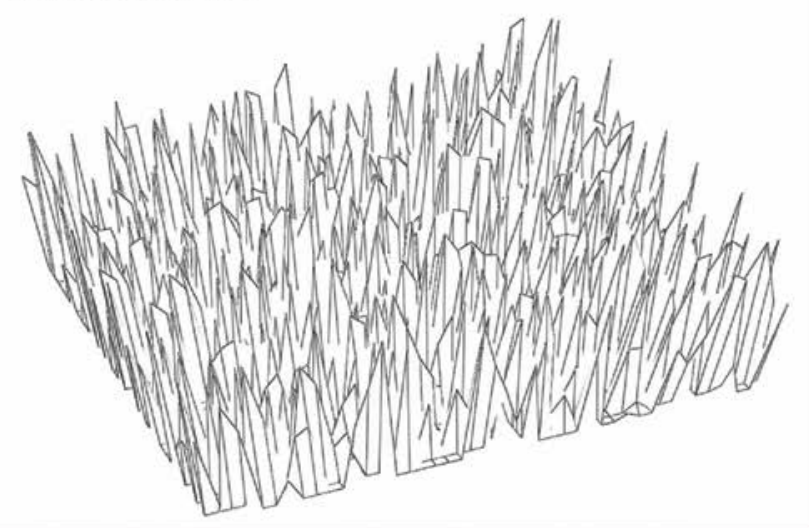

Figure 1. Smooth, rugged, and random fitness landscapes.

Source: Figures produced by the authors using QtiPlot. 


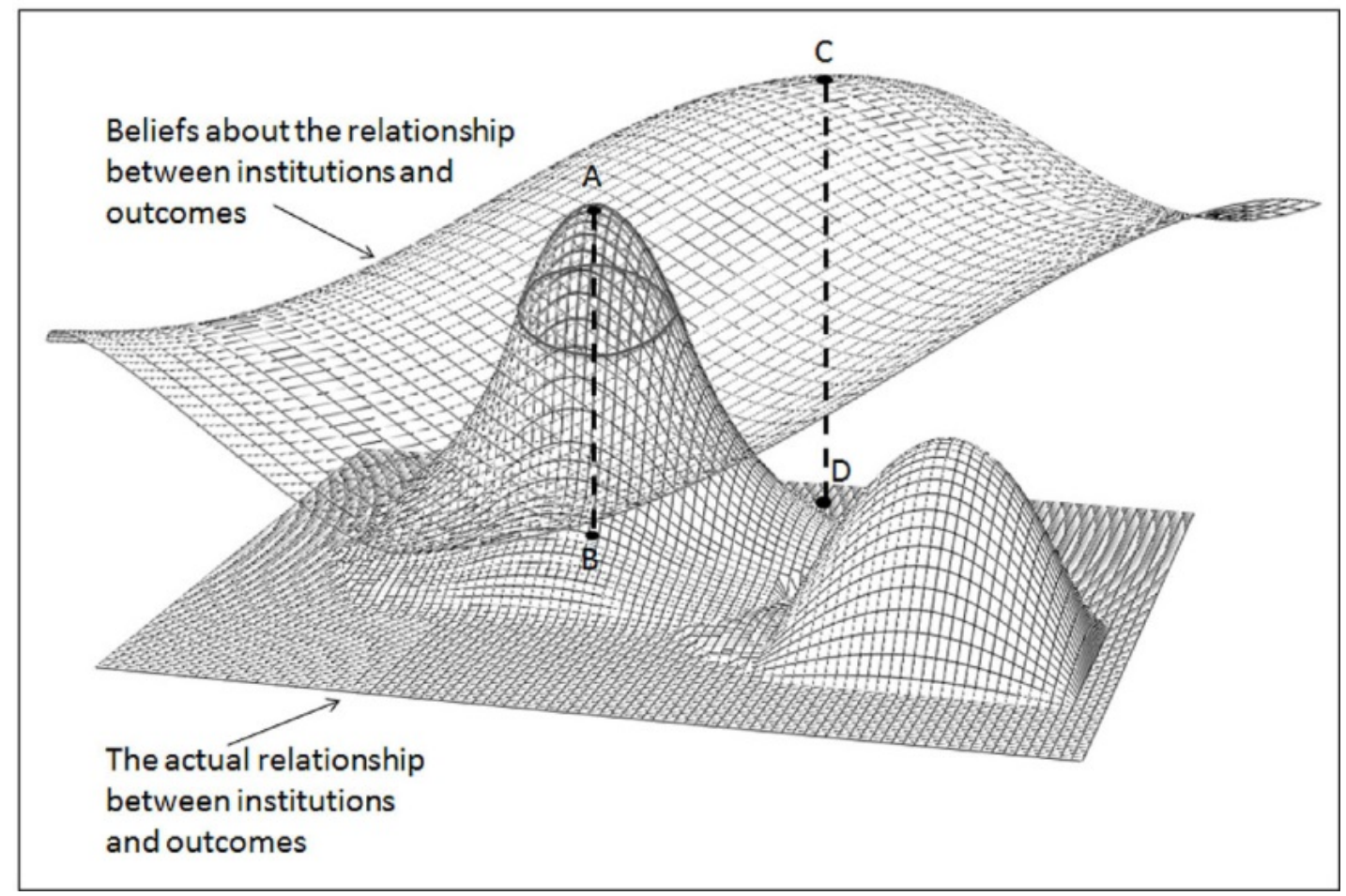

Figure 2. The actual and beliefs.

Source: Figures produced by the authors using QtiPlot. 

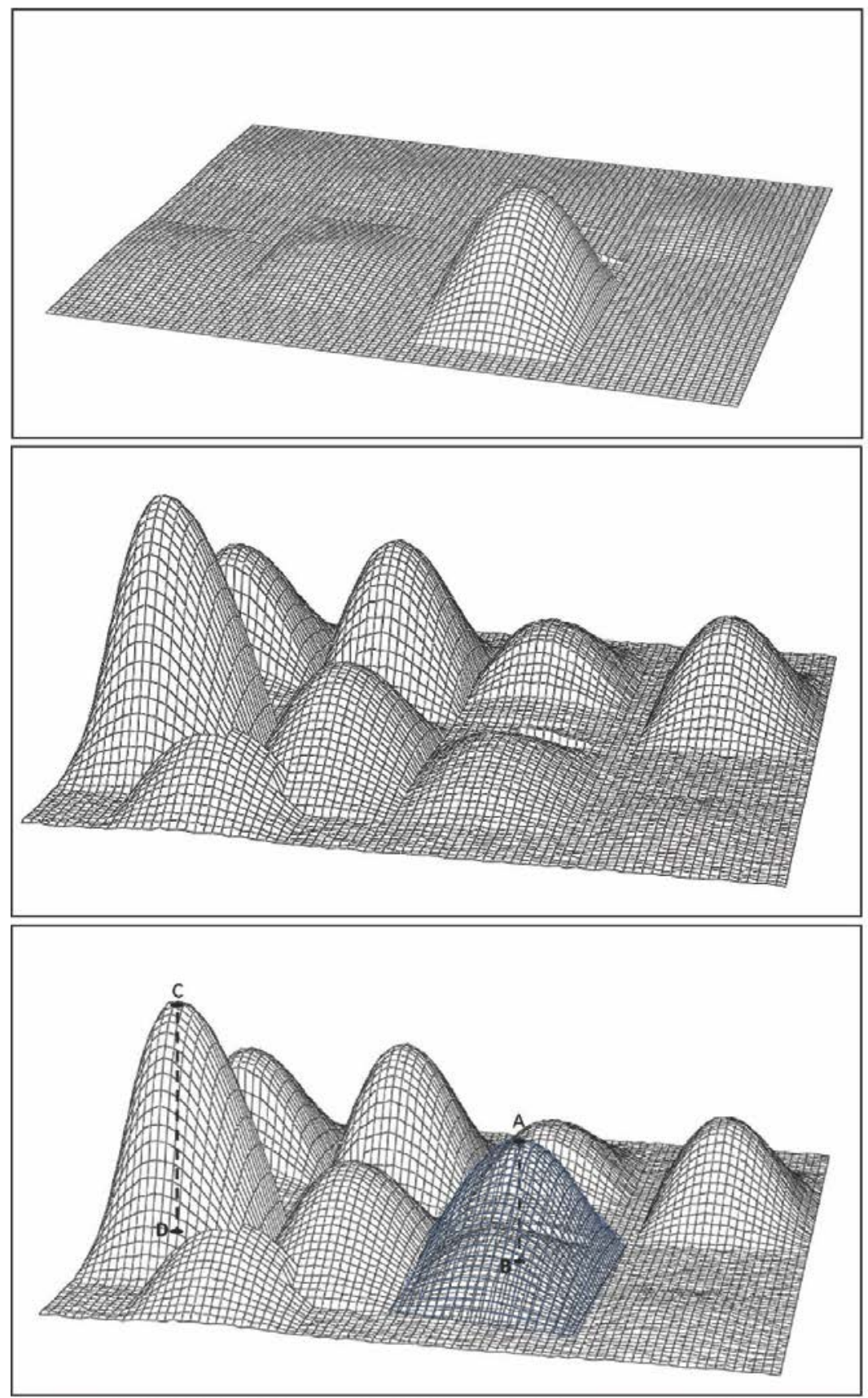

Figure 3. Stages of economic growth vs. economic backwardness.

Source: Figures produced by the authors using QtiPlot. 

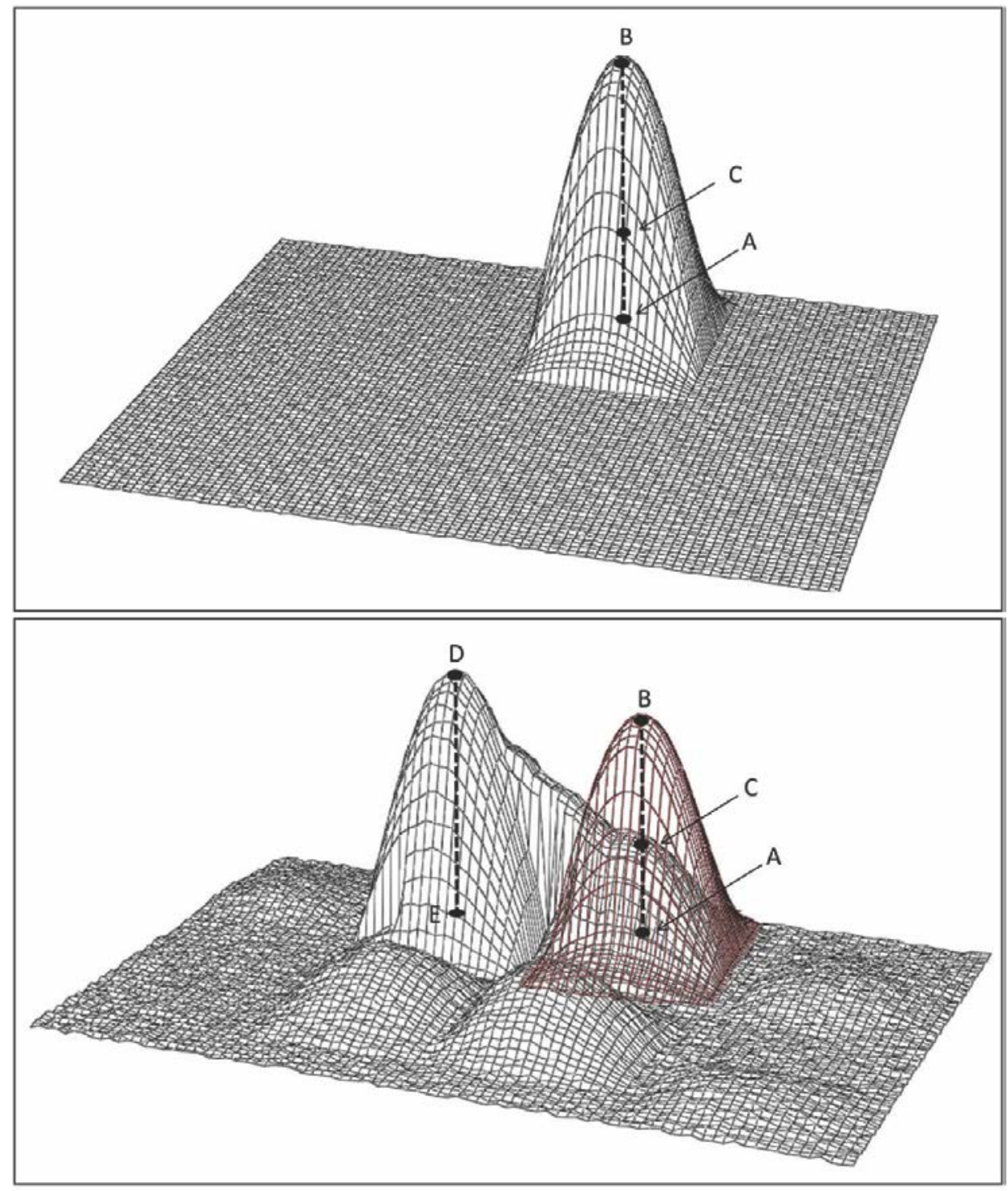

Figure 4. Hirschman's Hiding Hand Principle in fitness landscapes.

Source: Figures produced by the authors using QtiPlot. 


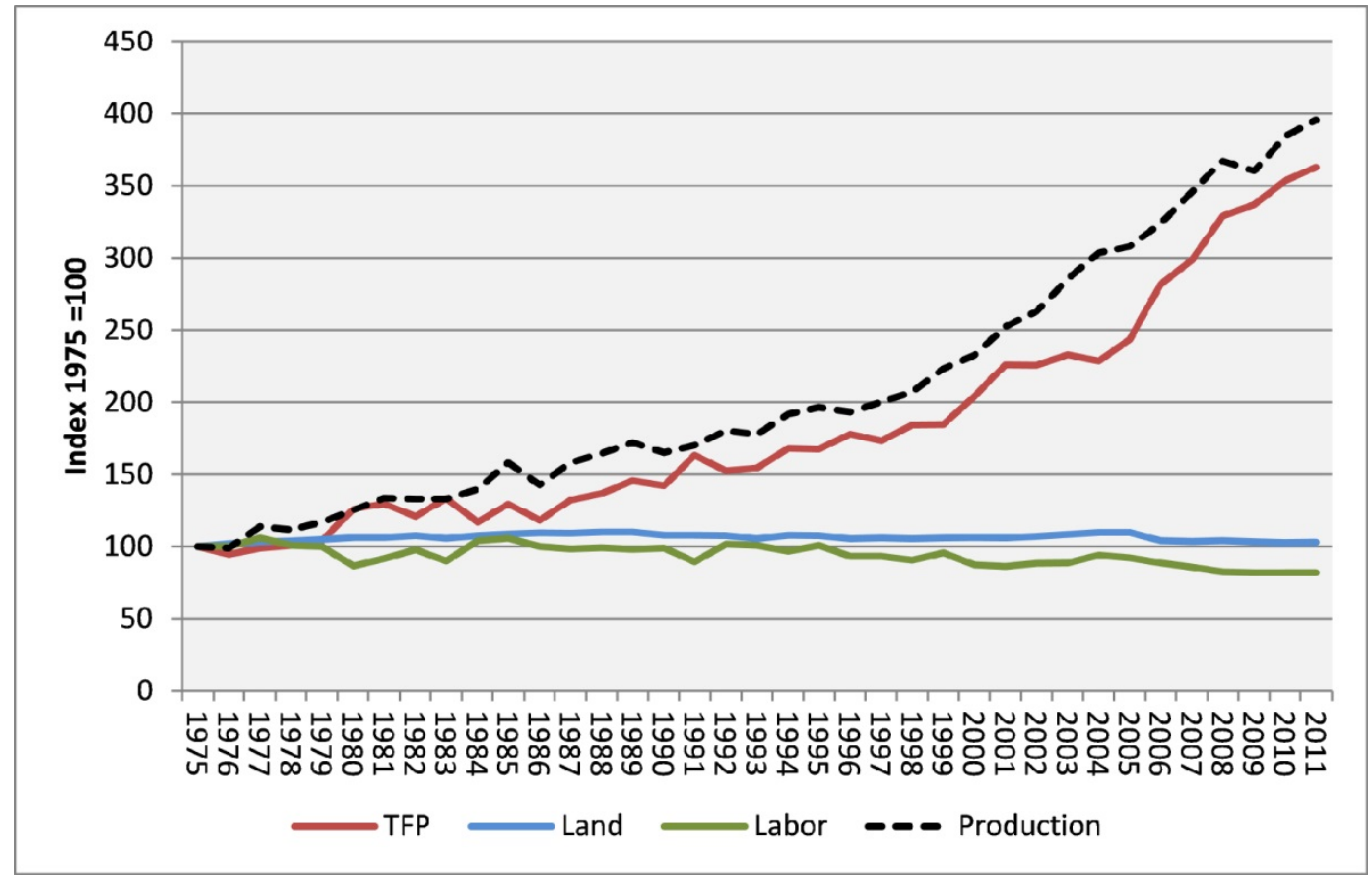

Figure 5. The evolution of production, land, labor, and TFP in Brazilian agriculture. Source: Data from Gasques et al. (2012). 


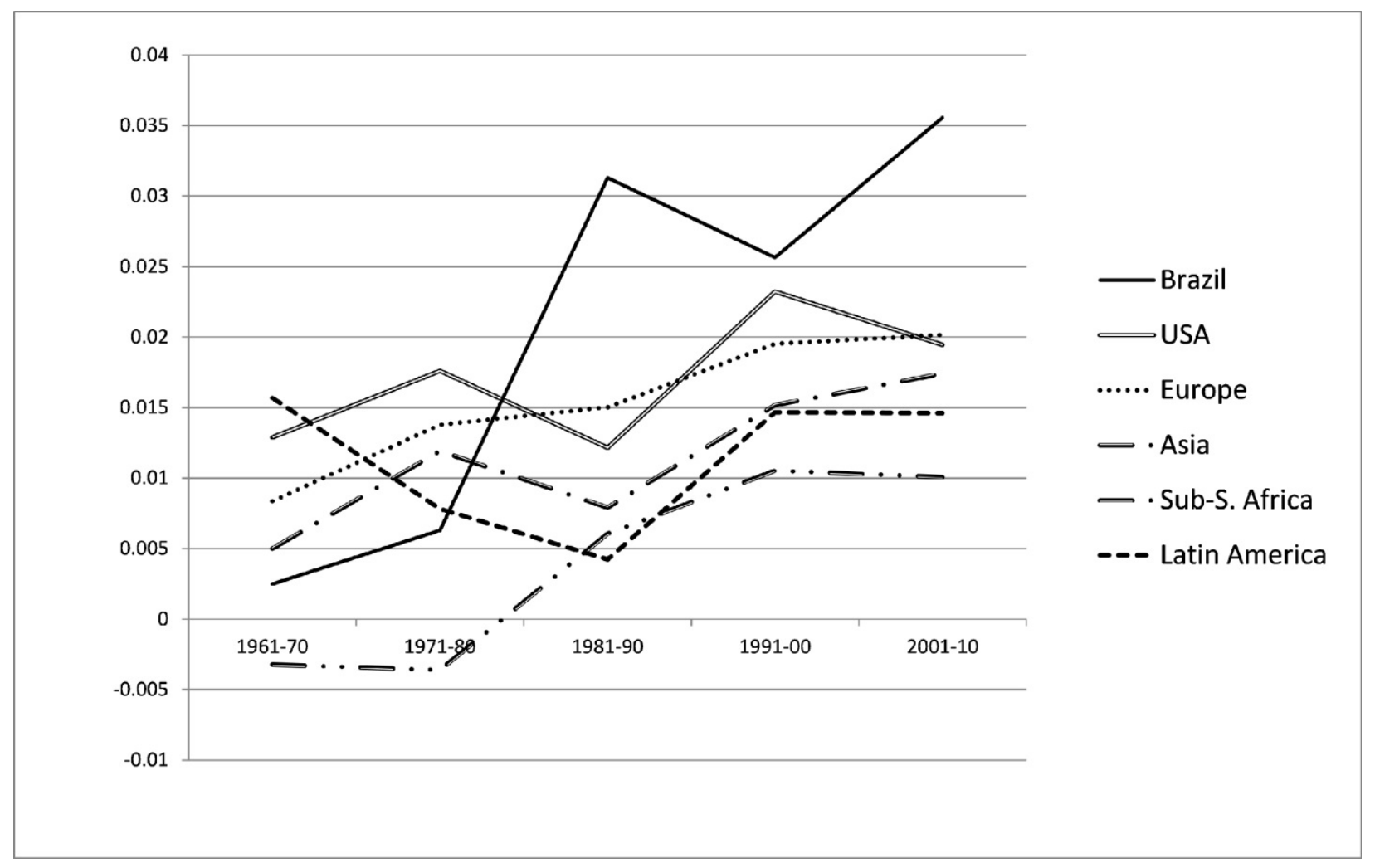

Figure 6. The evolution of TFP across countries.

Source: Compiled with data from USDA-Economic Research Service: International Agricultural Productivity. http://www.ers.usda.gov/data-products/international-agriculturalproductivity.aspx\#.UsVs67SzSJQ. 


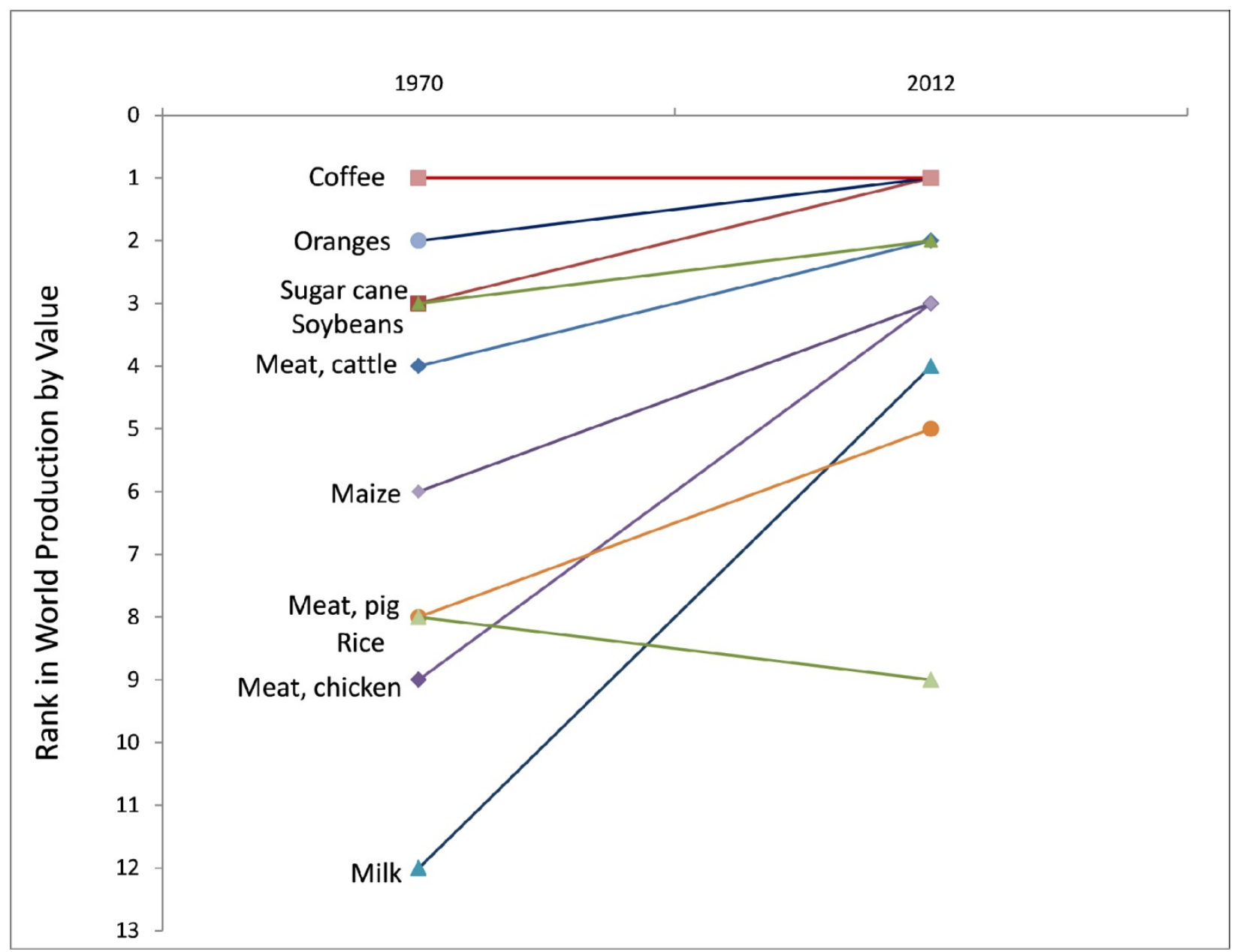

Figure 7. Brazil's rank in 1970 and 2012 as a producer of the top-ten most valuable crops and livestock products of 2012.

Source: FAOSTAT (http://faostat.fao.org). 